\title{
Advice and Advocacy: Ten Years of the Regional Stability in South East Europe Study Group
}

\author{
Ernst M. Felberbauer, Predrag Jureković, and Frederic Labarre ${ }^{1}$
}

\section{Advocacy and Advice: Supporting Regional Stability}

Advocates and advisers share a passion for the region they work in, but they are separated by the quality of their functions. Advocates are practitioners of reform and reconstruction working in the region, while advisers propose (but, ideally, do not proselytize) decision options. Dictionaries define advice as the "an opinion given to someone about what they should do in a particular situation," whereas advocacy is defined as "the act or action of supporting an idea, way of life, person, etc." ${ }^{2}$ Rarely is the English language so clear in its distinctions between two neighboring concepts. Both advocates and advisers, however, are often criticized for appearing to be too ready to offer opinions, and not being receptive enough to the realities on the ground and the grievances or actual needs of the local population.

In 1998, the PfP Consortium of Defense Academies and Security Studies Institutes applied the innovative concept that academic and governmental representatives of hitherto hostile blocs and countries could sit together around the same table and discuss - in the spirit of the Partnership for Peace - solutions for conflict resolution. In many cases (Serbia and Russia spring to mind immediately) it was one of the few politically acceptable fora of integration to join. Some countries have had the benefit of their own privileged modes of interaction with NATO, but they are eminently political. The PfP Consortium also has a political vision, but it is sublimated through its academic and scientific character, which means that, in the event of a crisis, such as the one that put NATO into opposition with Russia over Kosovo, the subtlety of this agenda does not lead to a collapse of cooperation.

Although the idea of enlarging the North Atlantic Treaty Organization was already occupying the minds of diplomatic and defense staffs in most Eastern and Central European countries between 1995 and 1998, for many of them the PfP Consortium represented the only forum where they could sit side-by-side with their future Alliance colleagues and counterparts. The educational value of the concept is therefore evident. Issue by issue, region by region, the PfP Consortium succeeded in developing a spirit of understanding between groups and individuals who until recently had been adversaries. This spirit predated every concrete invitation for membership, and fostered the courage to tackle many controversial issues (with varying degrees of success). It has been noted, for example, that rarely could Azeris and Armenians, Serbs and Croats, or

1 Ernst M. Felberbauer is Head of Research Management at the Austrian National Defence Academy; Predrag Jureković is Senior Researcher at the Institute for Peace Support and Conflict Management at the Austrian Military Academy, and co-chair of the RSSEE Study Group; Frederic Labarre is a regular contributor to the work of the Study Group.

2 Longman's Dictionary of Contemporary English (New York: Longman, 1990), 15. 
Kosovo Albanians and Serbs find themselves together debating the case of NagornoKarabakh, of the Krajina, or of Mitrovica in a Chatham House rule-protected, apolitical forum.

It is this idea that propelled the Austrian Ministry of Defence to co-sponsor a study group on South East European security in 1999, and to begin convening the first workshops in 2000. The impact of this decision (if only indirectly) can be measured in the success of many Western Balkan countries in integrating into European and Atlantic frameworks. In 2004, Slovenia became a member of both the EU and NATO. Andsome would say against all reasonable odds-Albania and Croatia formally joined the Alliance in 2009, and the rest of the states in the region are firmly setting their sights first on NATO and then EU membership. Two core functions of the study group thus far have been to serve as a platform for building confidence and as a "neutral" platform to facilitate the exchange of different views in politically sensitive circumstances. Thus, the format enabled contacts between Edita Tahiri, the advisor of the then-president of Kosovo, Ibrahim Rugova, and representatives of Serbian think tanks shortly after the end of the Kosovo war. In Spring 2008, shortly after the independence of Kosovo had been unilaterally declared by its parliament, a study group meeting on the Kosovo development brought together today's Serb State Secretary in the Kosovo Ministry, Oliver Ivanović, with analysts from a Kosovo-Albanian think tank. There are strong expectations that a Study Group on the Southern Caucasus could again achieve comparable results for that conflict-torn region through the transmission of lessons learned from the Western Balkans.

In the spring of 2000, Austria convened its first "Crisis Management in South East Europe" Study Group meeting. The rapidly improving security situation in BosniaHerzegovina and Kosovo warranted a name change to "Regional Stability in South East Europe" in 2003. The format of the meetings, however, has not changed. Workshops have been held twice a year for the past ten years, one in Austria and the other one in the region (Tirana, Ohrid, Dubrovnik, Sofia, Istanbul, Cavtat, Budva, Belgrade, and Sarajevo have all hosted study group meetings). The workshops have provided an opportunity for civil society actors from the region to introduce practical conflict resolution ideas to each other and to international actors alike. It is extremely important to note that the study group has never been an ivory tower, filled with members who were divorced from the realities on the ground. Proof of this is the timeliness with which the discussion topics were chosen year by year. If a new security issue of importance surfaced, the group would move quickly and pave the way to address it. To demonstrate how nimble the study group is, it successfully managed to collect advice and opinion on the subject of the Presevo Valley crisis as it was developing in May 2001, and integrated it in the subject of its Reichenau conference on ethnic heterogeneity. Therefore, the network rapidly became a receptor of information and regional grievances, not an emitter of so-called "solutions" for the locals to apply. 


\section{Regional Stability: A Process of Conflict Management and Resolution}

As defined by this study group, "regional stability" means to strive for cooperative political, economic, cultural, and military relations in areas that have passed through wars, where the political and interethnic relations are still partly characterized by conflict, or that are afflicted with security problems due to differing geo-strategic interests of regional or global actors. The activities of the Study Group on Regional Stability in South East Europe (SG RSSEE) have contributed at an academic level to enhance regional cooperation and to focus attention on the key issues for regional stability. Inasmuch as the topics and projects of the SG RSSEE since its beginning have been connected with the main trends in the process of stabilization and peace-building, in the following section we will cite some milestones of this complex endeavor.

Since the war in Bosnia and Herzegovina was terminated by the Dayton Accord in 1995, and even more evident after the ending of the NATO operation "Allied Force" in Kosovo in June 1999, the so-called Western Balkans became one of the main target regions for international support in terms of military, political, and economic peacebuilding measures.

The international support as such has gone through a substantial change in the last fifteen years. The first missions - as was the case with the NATO-led "Implementation Force" (IFOR) in Bosnia and Herzegovina - were above all aimed at preventing the outbreak of new hostilities between the parties of conflict. Democratic changes inside the two regional core actors, Croatia and Serbia, in the post-Tudjman and post-Milosevic era since 2000 have enabled international actors to support a positive transformation of the formerly violent conflicts, an intervention that extends beyond the prevention of new wars.

The more ambitious goal focused on the recent past has been to make partners of former enemies. Of crucial importance for approaching this goal is the prospect offered by NATO and the EU to the Western Balkan countries of joining these two organizations, and the common interests and democratic standards that are the result of the integration processes. Albania and Croatia's accession to NATO membership in April 2009 has been an encouraging signal for the whole region that substantial reforms and a cooperative policy can lead to positive changes, although the road to achieving this goal sometimes seems to be very rough indeed. The analysis of the obstacles to achieving a cooperative policy in the region and proposing ways of dealing with them is seen by the Study Group on Regional Stability in South East Europe as one of its most important tasks.

The fact that supporting positive peace in a post-war region is a very complex and demanding project has been demonstrated in the last fifteen years by the international peace-building activities in the Western Balkans which, compared to other post-war regions in the world, is a rather small area. In this respect, we should remind ourselves of some figures: since 1995, the UN, NATO, and the EU combined have deployed a total of nine military Peace Support Operations (PSOs) in the Western Balkans, each with different mandates according to the necessities in different stages of the peacebuilding process. 
In Bosnia and Herzegovina, for instance, IFOR - with its main task of implementing the military aspects of Dayton 1995 - was replaced by the NATO-led follow up mission "Stabilization Force" (SFOR), which had the mandate to support the international civilian presence in implementing the political and human rights elements of the peace agreement. SFOR again was followed by the "EUFOR-ALTHEA" mission in 2004, which is still deployed in Bosnia and Herzegovina. Although "EUFOR-ALTHEA" is still provided with an executive mandate according to Chapter VII of the UN Charter, its future presence is planned to primarily focus on supporting the local security forces in the field of security sector reform. For this purpose, the EU military mission will cooperate closely with the NATO-led mission, considering the political goal to increase Bosnia and Herzegovina's functionality as a state and to provide assistance to the country in making progress toward joining the Euro-Atlantic institutions.

In the FYR of Macedonia, the "United Nations Preventive Deployment Force" (UNPREDEP) - which was deployed in the second half of the 1990s - tried to prevent the spill-over of the Kosovo conflict into Macedonia. Unfortunately, this generally successful mission was terminated too early because of a diplomatic conflict between FYROM and China. In 2001 when a near-civil war situation was defused by diplomatic efforts from the international community, new Peace Support Operations were launched in Macedonia. NATO's operation "Essential Harvest," which was tasked with collecting the weapons of KLA fighters in FYROM, was followed by the NATO-led missions "Amber Fox" and "Allied Harmony" (and the latter by the EU-led operation "Concordia") to support the peace-building process in FYROM. This EU military mission in FYROM was completed in December 2003. As a result of the still tense interethnic situation in its operational area, the "Kosovo Security Force" (KFOR), deployed in 1999, has remained a Peace Support Operation highly focused on security protection.

Aside from these military operations, several police and civilian peace support missions launched by the EU have contributed to the improvement of the overall security situation in the region and provide support for the reform of the security sector in the Western Balkans. The most comprehensive civilian ESDP mission at present in the region (and, in fact, in the world) is EULEX-Kosovo, with approximately 1900 international personnel that aim to back up Kosovo's police, customs, and justice system. The main political framework for the regional process of peace-building is provided by the EU and its "Stabilization and Association Process" for the Western Balkan countries. It defines the road map and provides substantial assistance in regard to future EU membership.

The EU as such has become deeply involved in state-building processes in the region, as is in particular demonstrated by the important function of the High Representative/EU Special Representative in Bosnia and Herzegovina, an office that was established to push forward the peace process with strong legislative and executive powers. This post has had recognized positive effects on the peace- and state-building process, but it has also been criticized by the affected groups in Bosnia and Herzegovina due to its questionable compatibility with the goals of democratization. The scope of the of- 
fice's powers indicates that international peace support in the case of the Western Balkans has departed substantially from traditional concepts of peacekeeping and peacemaking, and has ventured well into the territory of state-building.

The EU and NATO's efforts to prepare the Western Balkan countries for future membership has without doubt had a positive influence on regional cooperation, which is certainly a precondition for transforming a "negative peace" into a situation of "positive peace." During the last ten years, in the wake of the rapid pace of the EuroAtlantic integration processes, a lot of new institutions were founded to enhance regional cooperation. In this context in particular, the former Stability Pact for South East Europe has to be mentioned, which was followed by the Sarajevo-based Regional Cooperation Council (RCC), established in 2008. The RCC supports and assists regional projects in the fields of economic and social development, energy and infrastructure, justice and home affairs, security cooperation, and building human capital, and is also engaged in parliamentary cooperation.

It is important to mention that the RCC-like the regional political platform represented by the South East European Cooperation Process - are guided by the principle of regional ownership. The membership of all Western Balkan countries in the Central European Free Trade Agreement (CEFTA) provides the opportunity to significantly enhance economic relations in the region. Last but not least, the activities of this study group within the framework of the PfP Consortium can be regarded as an important forum for regional cooperation. Considering the fact that analysts and policy advisers from the whole region meet twice a year in order to arrive at common recommendations regarding the challenges they are facing in the stabilization process - a conversation that could not take place in any other forum - the study group has clearly proved its worth.

Generally viewed, successes in the post-war-period are obvious. An indicator of this is the interest shown in the Caucasus region and in parts of Africa for the "Balkan model" with regard to conflict resolution. However, this should not lead to the incorrect assessment that all of the region's problems have been solved, and that international support for the region is no longer required. On the contrary, the process of conflict transformation is currently in a sensitive phase, as is demonstrated, for instance, by the difficult state-building process in Bosnia and Herzegovina, the still tense relationship between Belgrade and Priština/Prishtina, and the fragile state of interethnic relations in FYROM. The continuation of integration policies is crucial for dealing positively with these challenges.

\section{The Future of Regional Engagement and Stability in the Western Balkans}

In support of these endeavors, the RSSEE Study Group has welcomed the advocacy of some 350 experts and practitioners during the last ten years. Government officials, police and military officers, NGO representatives, think tank analysts, academics, and journalists have been provided a judgment-free, non-political forum where they have shared in the spirit of collegiality the importance of a free press, the improved rule of law, multi-ethnic bureaucracy, improved civil-military relations, among many other 
topics. They have argued for tolerance in refugee returns, and stressed the need for market liberalization. In addition to making these conversations possible, the study group has made the crucial leap of imagination and action by taking the conclusions of each workshop over the past ten years and distilling them into the form of applicable advice. As can be expected, this advice found the loudest echo in the region, attracting the attention of local partners and institutions of both official and non-governmental background, and influencing major actors engaged in the field. This advice, through the conduit that the PfP Consortium affords to its funding agents, is finding its way to NATO and European institutions and ultimately to the United States' Secretary of Defense.

Moreover, the study group serves an important communication and information function with and within South East Europe. The efficiency and reach of that tool is enhanced through the regular publication of the Study Group Information series by the Austrian Ministry of Defence and Sports, and through the occasional papers germane to South East Europe published in Connections. The Austrian National Defence Academy has published thirty-five such proceedings in the ten years of the study group's existence. A rapid Internet search on any of its contributors will reveal how broadly these publications are used in the region. Through this simple process of advocacycum-advice, actors and interested parties from the region (and beyond) ensure an information loop that creates action.

The year 2010 is the occasion for many anniversaries for the Austrian Ministry of Defence and Sports. First and foremost, it marks fifty years of the ministry's participation in peace missions, extending from Katanga (today's Democratic Republic of the Congo) in 1960, up to its latest mission in Chad, under UN and EU mandates. Second, it marks the coincidence of a twin anniversary: that of Austria's membership in the EU and accession to the Partnership for Peace Program, and second, it marks ten years of active participation in the PfP Consortium and the RSSEE Study Group.

The RSSEE Study Group is the cornerstone of Austrian security policy oriented toward maintaining and extending stability in the Western Balkan. It can be said that the study group's existence itself has had a beneficial impact in pacifying this troubled region. We are looking forward to another ten years of collaboration with the PfP Consortium, with our South East European partners, and to the possibility of transmitting the lessons learned in this study group to other similar endeavors covering the Southern Caucasus, Central Asia, and even Africa. 
SUMMER 2010

\section{Bibliography}

Longman's Dictionary of Contemporary English. New York: Longman, 2008. 